loss of the basement membrane (see Fig. 1). Microvesicles, spongiosis and an increase in mitosis were seen in the epidermis. The histology is consistent with that seen in contact dermatitis in the adult ${ }^{3}$. Patch testing 2-6 weeks after birth of unsensitized neonatals (six premature and six full-term) gave negative results. Punch biopsy with histological examination of a patch test area at $48 \mathrm{hr}$. in an unsensitized premature neonatal, aged three weeks, also failed to show an inflammatory reaction.

Our findings show the following striking similarities to previous work on antibody formation in new-born infants ${ }^{4}$ : (a) delayed-type hypersensitivity and antibody formation can both be induced in premature infants during the first month of life; (b) new-born infants are inconsistent in their capacity to develop these two types of immune response; (c) premature infants become sensitized and form antibodies as efficiently as normal new-born infants.

This work suggests that the older human foetus might be capable of an immune response if an appropriate antigenic stimulation could be administered in utero. The possibility is not excluded, however, that separation from the placenta is an essential step in the maturation of the immune mechanism.

We thank Dr. Philip Prose, of the Department of Pathology, for his assistance in the processing and interpretation of the skin biopsies.

This work was aided by grants from the Association for the Aid of Crippled Children, the National Institutes of Health $(E \quad 1821(C-2))$ and the Commission on Immunization of the Armed Forces Epidemiological Board.

Jonathan W. Uhr
Joseph Dancts
Charlotte Grantz NeumanN

New York University School of Medicine, and Bellevue Hospital, New York.

1 Uhr, J. W., Nature, 187, 957 (1960).

2 Straus, H. W., J. Allergy, 2, 137 (1931).

3 Allen, A. C., in "The Skin", 204 (C. V. Mosby Co., St. Louis, 1954).

4 Dancis, Y., Osborn, J. J., and Kunz, H. W., Pediatrics, 12, 151 (1953)

\section{The Polychæte Family Longosomidae in New Zealand}

Is 1944 Hartman $^{1}$ described a new polychæte species Longosoma catalinensis from off Long Point, Catalina Island, southern California, founding a new family, the Longosomidae, to contain it. The original description was based on a single specimen, but afterwards in 1957 she reported 34 specimens from three stations off southern California in depths of 7-45 fathoms. According to Hartman ${ }^{2}$ the species may have its affinities with the Paraonidae; but the possession of long, paired, grooved palpi, resembling those of spioniform annelids, allies it to the disomid and magelonid families.

The genus and family have not been rocorded to date from other than the original locality, hence it was of great interest to obtain specimens of a polychæte, which at first were thought to bo specifically identical with $L$. catalinensis, from such a distant locality as Hawke's Bay, New Zealand. The New Zealand specimens, numbering 27 , were obtained in August 1956 from twelve stations, in depths of 8-64 fathoms, by Dr. D. Hurley of the New Zealand Oceanographic Institute, and I am indebted to him for the opportunity to report on this interesting discovery. On a recent visit to California, the New Zealand specimens were compared with the type of $L$. catalinensis and Dr. Hartman agrees that the differences justify the founding for them of a new species of the genus Longosoma. As in L. catalensis they have tho body divided into an anterior region of nine short setigerous segments and an abdomen with greatly prolonged cylindrical segments, the abdominal parapodia consisting of ridges with double rows of simple setæ. The New Zealand species differs in its larger size, the largest posteriorly incomplete specimen of $L$. catalinensis with four abdominal segments measuring $25 \mathrm{~mm}$., whereas a comparable specimen of the former measures $55 \mathrm{~mm}$. They are also much more robust, with the thorax measuring up to $3 \mathrm{~mm}$. across, and with the thoracic setæ heavier and more numerous. The proportionate length of the abdominal segments also differ, but the greatest difference is to be seen in the arrangement of the abdominal parapodia. In $L$. catalinensis the abdominal parapodia are low ridges encircling two-thirds to three-quarters of the body and leaving the ventrum plain, while in the New Zealand species the ridges are much more prominent and completely encircle the body. A full description of the species will be published separately.

It is of interest to note that Hartman records her specimens from similar depths in very fine sand and silt and in temperatures of about $14.9^{\circ} \mathrm{C}$. The bottom sediments from the stations where the New Zealand specimens were obtained are recorded as ranging from fine grey sands to fine sandy muds with bottom temperatures in the region of $13 \cdot 0-13 \cdot 3^{\circ} \mathrm{C}$. According to Hartman, L. catalinensis is associated with other polychrtes, a maldanid, Axiothella rubrocincta (Johnson) and a nephthyid Nephthys ferrunginea Hartman, and a cumacean, probably Diastylopsis tenuis Timmer. Some thirty-six species of polychætes have been recorded from Hawke's Bay in association with Longosoma, among the dominant being a nephthyid, Aglaophamus verrilli (McIntosh), and two species of maldanids of the genus Asychis. Other dominants include the cumaceans Diastylopsis elongata CaIman and $D$. crassior Calman (belonging to the same genus as the cumacean associated with $L$. catalinsis), the holothurian Cucumaria oconoides (Dendy), ophiuroids of the genus Amphiura and the bivalves Dosinia lambata (Gould) and Maorimacta ordinaria (Smith).

The present recorded distribution of the family Longosomidae, southern California and northern New Zealand, represents a very disjunct distribution. In both localities the representatives of the family are not uncommon, and it is therefore surprising that it has not been recorded elsewhere. Additional distributions will, however, probably be recorded when similar shallow bottom areas of the Pacific basin are studied in detail, as has been done for the areas off southern California and Hawke's Bay, New Zealand. It is of interest that similar techniques were used in processing the bottom samples from the two regions. A similar disjunct distribution is recorded for the species of the echiuroid genus Urechis, which has been recorded from southern California, southern Chile, New Zealand, and $J_{\text {Japan }}^{3}$.

\section{G. A. KNox}

Department of Zoology,

University of Canterbury, Christchurch,

New Zealand.

1 Hartman, O., Rep. Allan Hancock Pacific Exped., 10, 321 (1944).

2 Hartman, O., Rep. Allan Hancock Pacific Exped., 15, 335 (1957).

${ }^{3}$ Knox, G. A., Trans. Roy. Soc. N.Z., 85, 141 (1957). 